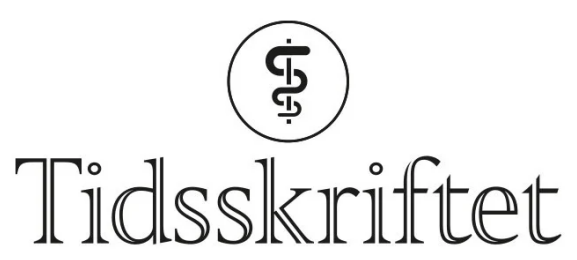

DEN NORSKE LEGEFORENING

\title{
Alvorlige ulykker i et langstrakt land
}

TIDLIGERE I TIDSSKRIFTET

JULIE DIDRIKSEN

Tidsskriftet

Norge er et land med store avstander, og i 1917 kunne man ikke bli hentet av helikopter og lagt raskt inn på sykehus hvis det gikk galt. Det var ikke uvanlig at legene brukte hele dagen bare på å komme seg til pasienten, og når de først kom dit, kunne de bare gjøre det beste ut av situasjonen. Under følger en skildring av to alvorlige ulykker fra nr. 16/1917 (Tidsskr Nor Lægeforen 1917; 15: 702-3).

To spiddede mænd i samme bygd.

\section{AV H. MEYER}

I [en bygd] var en middelaldrende mand beskjæftiget med at ta imot høi, som paa en løipestreng blev befordret ned til bygden fra en utslaat i fjeldsiden. Løipestrengen blev spændt med et slags spil, en rund træstamme, som ved tapper var fæstet i 2 opstaaende støtter. Med en jernbrækstang gjennem et hul blev stammen dreiet rundt, indtil strengen var stram, og blev saa stoppet ved at den butte ende av brækstangen stod mot jorden, mens den spisse ende raket opad og fortil. 


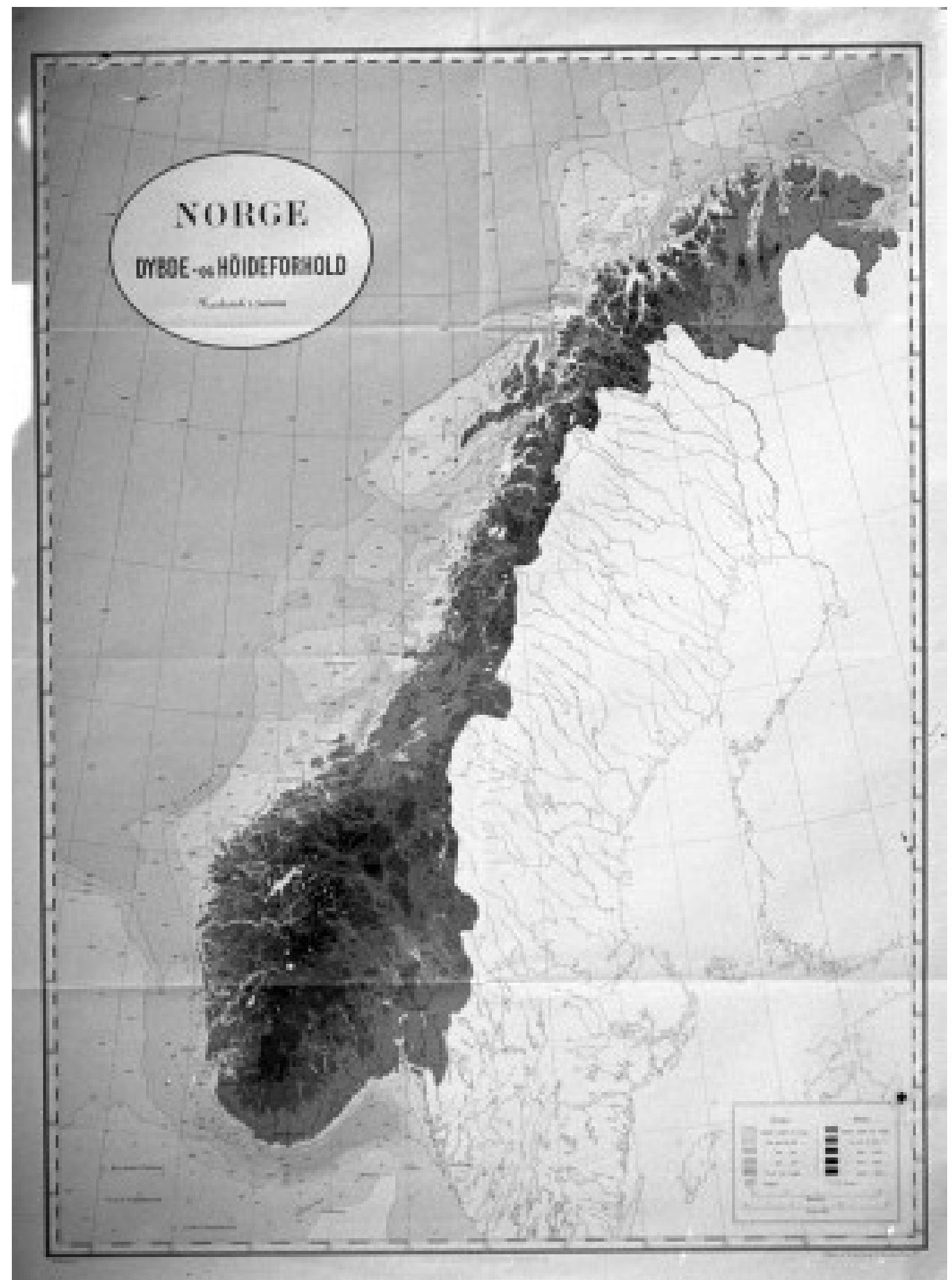

Illustrasjonsfoto: Severin Worm-Petersen / Norsk Teknisk Museum

«Ekspressen hadde 3 gamle norske mil at ro, ogjeg likesaa langt, saa hele dagen gik med, førjeg kom frem»

Av en nedsusende høibør blev manden kastet voldsomt bakover mot brækstangen, som gik ind i bakhodet og ut gjennem panden. Han blev med magt trukket av og bragt hjem. Der gik straks bud efter mig. Ekspressen hadde 3 gamle norske mil at ro, og jeg likesaa langt, saa hele dagen gik med, før jeg kom frem. Efter beskrivelsen av læsionen ventet jeg at finde ham død; men han levet endnu, dypt snorkende i koma. Jeg kunde ikke gjøre andet end at forbinde saarene, ordne leiet og ta hans urin. Han levet endnu i to døgn uten at komme til bevissthet.

«Da jeg fik min kateter tilbake, hørte jeg, at han var frisk og vel fornøiet» 
En 18 aars gut fra samme bygd var en vinter i marken paa ski. Herunder faldt han over en avhugget busk, hvis spisse ende stod ret tilveirs, og fik denne op gjennem anus. Da jeg tilsaa ham, fandt jeg en oprevet anus, og utsivende urin viste, at blæren var lædert. Jeg la gutten à la vache i sengen, godt støttet av puter, la ind en Nelatons kateter à demeure, gav ham store doser opium, tilholdt ham at drikke og spise mindst mulig og instruerte omgivelserne angaaende stellet.

Jeg saa ham ikke mere; men da jeg fik min kateter tilbake, hørte jeg, at han var frisk og vel fornøiet.

Publisert: 22. september 2020. Tidsskr Nor Legeforen. DOI: 10.4045/tidsskr.20.0125

(C) Tidsskrift for Den norske legeforening 2023. Lastet ned fra tidsskriftet.no 26. april 2023. 